\title{
An open door for illegal trade: online sale of Strombocactus disciformis (Cactaceae)
}

\author{
Vania R. Olmos-Lau', María C. Mandujano' \\ I Departamento de Ecología de la Biodiversidad, Instituto de Ecología, Universidad Nacional Autónoma de \\ México, UNAM, Apartado Postal 70-275, 04510 México, DF, México \\ Corresponding author: María C. Mandujano (mcmandujano@gmail.com)
}

Academic editor: D. Evans | Received 24 February 2016 | Accepted 4 July 2016 | Published 22 September 2016

http://zoobank.org/CO7EDF96-B251-4176-A764-317D87421767

Citation: Olmos-Lau VR, Mandujano MC (2016) An open door for illegal trade: online sale of Strombocactus disciformis (Cactaceae). Nature Conservation 15: 1-9. doi: 10.3897/natureconservation.15.8259

\begin{abstract}
Online trade of CITES listed species has become a persistent threat which is difficult to measure and control. The use of online markets is growing day by the day as technology becomes more available and familiar to people of all ages and interests. Species trade can now be propagated remotely hardly without any real human interaction. We develop a quick-easy method to assess the online availability of the genus Strombocactus, a highly collectible cactus, to understand the real magnitude of this new form of threat and the possible menace it could be for these Mexican cacti. We used the Google.com site to do an online search in four languages (Spanish, English, French and German) for the offer of adult plants or seeds. We found specimens and seeds available in major online markets like ebay, amazon, cactusplaza.com and mercado libre. Plant price range from $€ 10.00$ to $€ 30.00$ plus shipping and handling. The plants were also offered in local online stores in countries like the USA, France, Germany, Australia, Czech Republic, the United Kingdom, and others; some sellers claim they have no obstacles for "shipping across countries" and others openly declare the natural localities where seeds were extracted. Only a minority of these online stores openly stated that the cacti were obtained from CITES registered nurseries or that the cacti were grown through propagules or seeds. Our method is easily transferable to estimate the illegal market for any species. There is an active online trade of Strombocactus species and other species listed in CITES without the necessary documentation. Compliance or other regulation mechanisms are needed in order to promote species conservation.
\end{abstract}

\section{Keywords}

Cactaceae, CITES, online trade, ornamental plant trade, wildlife trade

Copyright Vania R. Olmos-Lau, Maria C. Mandujano. This is an open access article distributed under the terms of the Creative Commons Attribution License (CC BY 4.0), which permits unrestricted use, distribution, and reproduction in any medium, provided the original author and source are credited. 


\section{Introduction}

Mexico is the main hot spot of native cacti biodiversity, there are approximately 600 species of Cactaceae family of which $80 \%$ are endemic (Ortega-Baes and GodínezÁlvarez 2006, 2007, Ortega-Baes et al. 2010, Novoa et al. 2014); because of their beauty and rarity, they are of great interest and are well represented in the ornamental plant market, particularly in Europe, and more recently also in Asia (Álvarez et al. 2004, Novoa et al. 2014). Strombocactus disciformis is one of the Mexican endemic species listed as vulnerable in the IUCN, due to its limited range restricted to ten localities and the population decline due to illegal overcollection of mature individuals (Gómez-Hinostrosa et al. 2013), and it is included in Appendix I of CITES (CITES 2014). It is also included in the Mexican red list (NOM-ECOL-2010, SEMARNAT 2010) as threatened, therefore a collection permit is needed for seeds and individuals and no commercial trade of wild specimens is allowed (SEMARNAT 2010).

Online trade has become a new threat for CITES species (CITES 2011). The use of online stores by the general public increases each day as technology becomes more accessible and familiar to people of all ages and interests. In present days the trade of species can be done without any real human interaction and distance is no longer an obstacle. Contacting a seller is simplified by finding an offer in an online store and by the use of e-mail. Although conventional trade routes are maintained through the shipping of goods, the widespread use and the unregulated nature of the internet make e-commerce a great concern to the Convention on International Trade in Endangered Species of Wild Fauna and Flora, since plants and their derivatives have become a widespread commodity in this new type of trade (Ceballos and Kepel 2009).

Only species subject to international trade can be included in the CITES Appendices, inclusion in the Appendices allows the regulation of international trade in endangered wild species through the issuing and control of permits which aim to guarantee that the trade of individuals is not detrimental to the survival of the species in the wild. These apply to regular and internet trade (Sajeva et al. 2013). All members of the Cactaceae, with the exception of 3 genera (Pereskia, Pereskiopsis, and Quiabentia) are listed in either Appendix I or II. International trade of plants listed in Appendix I for commercial purposes is prohibited and they can only be traded if they are artificially propagated, in which case they are treated as if they were included in Appendix II, for which an export permit must be issued (Article VII, paragraph 4 of the Convention) (Sajeva et al. 2013). Artificially produced hybrids may be traded with an artificial propagation certificate, while seeds, flowers and other derivatives of these hybrids are not subject to the Convention (CITES 2014). Seeds of CITES Appendix I cacti, including seeds from artificially propagated plants, require CITES permits (U.S. Fish and Wildlife Service 2010; CITES 2014). This also applies to seeds from all Cactaceae spp. exported from Mexico (CITES 2014).

Illegal international trade in species of wild flora, in addition to threatening survival of species, may be detrimental for the local use and fair sharing of benefits from utilization of species (CBD 2012). Mexico being the most important centre of biodiversity 
of cacti (Jiménez-Sierra and Torres-Orozco 2003, Ortega-Baes and Godínez-Álvarez 2006, Carrillo et al. 2005, Jiménez-Sierra and Torres-Orozco 2003, Martínez-Peralta and Mandujano 2009, Novoa et al. 2014), plays no important role in the commercial reproduction of cacti for trade and propagation activities are often hard to begin due to strong national regulations (Bárcenas 2003). This leaves locals in the sites of origin, who are usually low income peasants, with no other way of making use of the biological richness other than allowing collection by any visitor for a low income through illegal trade.

Internet monitoring of the illegal trade of species has focused mainly on animals (Kepel et al. 2004, CEEWeb 2007, Ceballos and Kepel 2009, Xianlin 2009, Pistoni and Toledo 2010). A study in 2013 concerning the cacti family suggested that only $10 \%$ of the plants traded through the internet were potentially legal (Sajeva et al. 2013). All reports have agreed that internet commerce is a growing threat to the regulation of illegal trade, but presents an opportunity to understand its scale and main targets. Internet monitoring can give a picture of the actual scale of trade (CEEWeb 2007). Taxon-specific internet monitoring allows the understanding of market opportunity as well as the threat presented by potentially unregulated commercial trade.

\section{Methods}

This methodology is relatively simple and easy to replicate to obtain a snapshot of internet commerce of a any species or genus.

An online search for the offer of adult plants and seeds of the genus Strombocactus was made during the period of March-April 2014, and reviewed at the end of 2015, using the https://www.google.com. The search was made in four languages using the following phrases: compra Strombocactus (Spanish), buy Strombocactus (English), acheter Strombocactus (French), and Strombocactus kaufen (German). Each website shown as a result in the browser was visited to determine if the website offered plants for sale, this was repeated until websites stopped being relevant on plant sales. The use of a common name for the search was not considered for this genus.

A database was constructed to organize the data and a summary chart was made to organize the information in the following categories: store name, link for the website, type (plant or seeds), quantity (number of seeds or size of the plants), species (different varieties recognized by collectors were considered), country of origin for the website, currency used, price, if they have or offer CITES documentation, and any other observations. For independent stores' websites, information on CITES was usually found under the terms and conditions or shopping tab. Advertisements in auction sites or big online websites like eBay or Amazon were also considered. All websites that didn't mention CITES information were contacted by e-mail, as potential buyer, inquiring about the need for CITES documentation and the origin of the plant or seeds.

An analysis of the UNEP-WCMC CITES Database, which holds the official record of CITES documented trade as reported by the countries member to the Conven- 
tion, for the genus was also carried out (http://trade.cites.org/) (CITES 2013, 2015) using the following filters: year range as from 1975 to 2014 and species as Strombocactus, no other filter was used.

\section{Results}

The genus Strombocactus is sold under different names recognized by collectors (Table 1). Some varieties of Strombocactus disciformis are more valuable than others. However, we notice the online market price for this species is no more than $€ 30$ for the biggest and therefore most ancient individuals and also considerably cheap prices for the seeds.

We found 32 online stores where either whole plants or seeds of the genus Strombocactus were available. Only six (19\%) state the plants they sell were obtained from CITES certified nurseries and will provide the documentation necessary: Duben Kaktus on eBay, Seeds Cactus, B\&T World Seeds, Kakteen-Haage, Uhlig-Kakteen, and Mesa Garden.

Out of the rest; $5(16 \%)$ mention CITES papers are necessary for the export but do not hold themselves responsible, 4 (13\%) don't deliver outside of the European Union and are therefore exempted of the need for CITES papers, 12 (38\%) mention that both plants and seeds are nursery cultivated from seed, in vitro or through grafting; and 8 $(25 \%)$ include the name of localities from which seed or plants have been collected of which $3(9 \%)$ include field collection numbers. These categories are not exclusive.

Regarding big online stores and auction sites such as eBay, Amazon and Mercadolibre, 24 publications were found. eBay contains the greatest number of publications, a total of 21, where only one of these sells plants from a CITES certified nursery, and another twelve declared specimens (both plants and seeds) came from nurseries or in the case of the latter where obtained from plants from a private collection.

Some online stores provide CITES documentation for international trade, $17 \%$ of stores in Germany, 25\% in the Czech Republic, 33\% in France and 50\% in Italy. Only two online stores out of the previously mentioned (one based out of Germany and one out of Czech Republic) sell plants directly from CITES certified nurseries (Figure 1).

Online commerce of seeds is abundant. Most of the seeds of this genus are sold in quantities of less than 100 seeds, but offers were found in some stores for 500-1000 seeds. As well, in some private websites and through the e-mail answers we received, the harvesting of seeds from the wild is admitted openly (Table 2), and some even provide information regarding a collectors code or the locality were they were obtained. Strombocactus seeds measure about $0.5 \mathrm{~mm}$ (Rojas-Aréchiga et al. 2013), therefore a single envelope can serve as a mean to move thousands of propagules unnoticed.

According to the UNEP-WCMC (United Nations Environmental Program's World Conservation Monitoring Centre) CITES trade database up until 1984 only whole live individuals were sold; subsequently trade in seeds began. Since 1976, 326 879 plants and 325433 seeds have been exported with CITES documentation. This last type of trade becomes more common than trade in whole plants from 1987 to the present day. The database also shows that since 1990 Mexico being the only country 
Table I. Online price of the different species and varieties of the genus Strombocactus (Cactaceae) for one unit in the case of plants and for 100 units in the case of seeds, during the period of March-April 2014, and reviewed at the end of 2015, using the https://www.google.com.

\begin{tabular}{l|c|c}
\hline \multicolumn{1}{c|}{ Species } & Seed prices $(\times \mathbf{1 0 0})$ & Plant prices \\
\hline Strombocactus disciformis & $2-10$ euros & 6-30 euros (depending on size) \\
\hline Strombocactus corregidorae & $7-12$ euros & 13 euros \\
\hline Strombocactus disciformis var. jarmilae & $2.5-15$ euros & - \\
\hline S. pulcherrimus (S. disciformis ssp. esperanzae) & $2-12$ euros & $21-26$ euros \\
\hline Strombocactus disciformis var. seidelli & $2.7-3.6$ euros & - \\
\hline
\end{tabular}

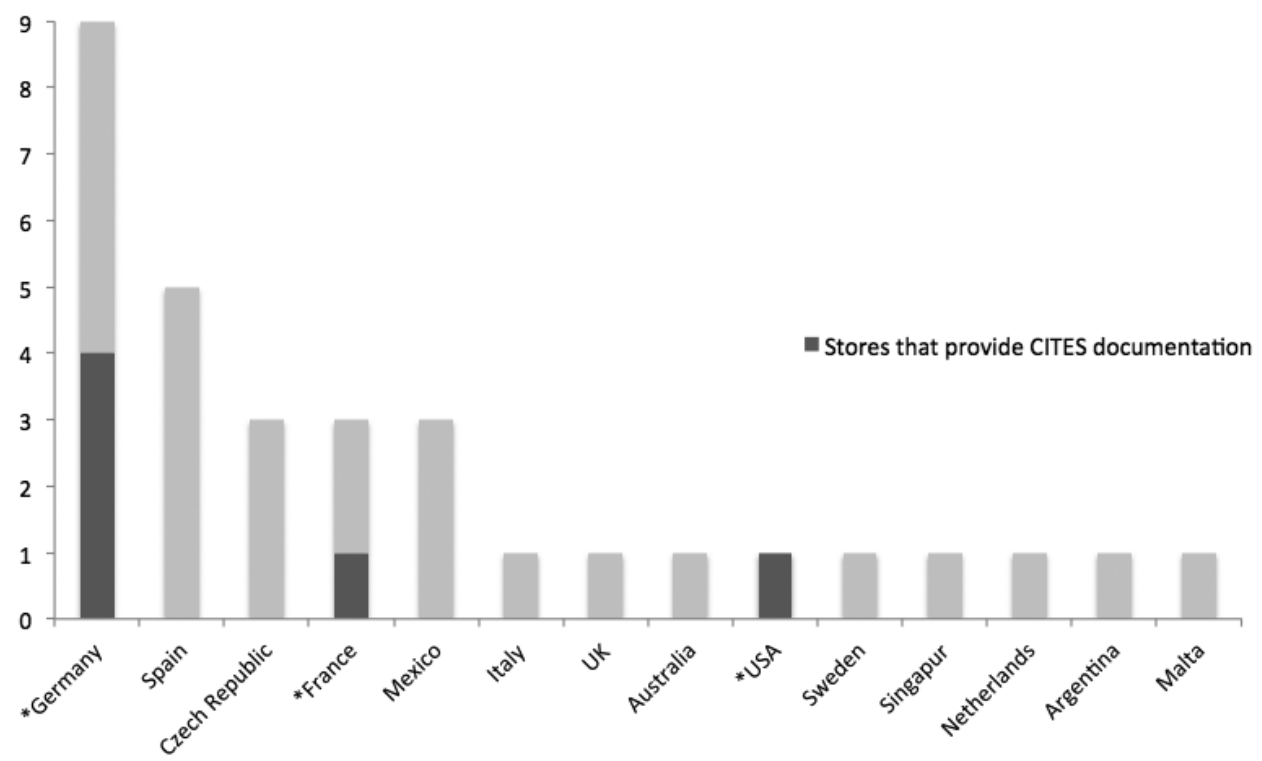

Figure I. Number of online stores per country that sell Strombocactus. The asterisk $\left(^{*}\right)$ represents countries where at least one online store offers CITES certified cacti.

Table 2. Number of online stores localities (abbreviated state in Mexico).

\begin{tabular}{c|l}
\hline No. of stores & \multicolumn{1}{c}{ Locality } \\
\hline 5 & Xichu, Gto. \\
\hline 5 & Peñamiller, Qro. \\
\hline 3 & Las Adjuntas, Gto. \\
\hline 3 & Peńa Blanca, Qro. \\
\hline 1 & Vizarrón, Qro. \\
\hline 1 & Maconi, Qro. \\
\hline 1 & Jalpán, Qro. \\
\hline
\end{tabular}

which holds Strombocactus in its natural habitat, began importing seeds from the USA, allowing non-range countries to profit from its national resources. Mexico has also imported live plants for reintroduction and scientific purposes (CITES 2015). 


\section{Discussion}

Most online stores may be implicated in illegal trade if they deliver specimens (both plants and seeds) internationally without CITES papers. The availability of seeds collected from wild specimens is particularly concerning. Plants can be easily sent in boxes marked with store codes, or seeds placed in envelopes. Generally, most stores that traded without the CITES documentation, didn't hold themselves responsible in case of confiscation but mentioned having no problem shipping internationally and that they do it often. This is particularly alarming due to the growing number of people that can easily offer CITES species in these stores protected by virtual anonymity, where once the publication is finished the user can leave the website making the identification of traders harder in the virtual world.

Research like this is relevant since it allows the use of an accessible and free tool like the internet to understand the magnitude of species trade. The UNEP-WCMC CITES database can be used to determine volumes of legitimate trade reported by CITES Parties and consistency between imports and exports (D'Cruze et al. 2015). We can find out which species are the most valuable, wanted and/or available; which may be useful to understand if the production of cultivated plants satisfies the demand for plants in the market. We can even track the appearance of recently described species in the international market of ornamental plants. Answers to these questions are especially vital for policy making by the bodies responsible for enforcing regulations, nature conservation and sustainable trade, as well as for possible future law amendments (Kepel 2004). The countries with the greatest volumes of production and sales can be identified, and most importantly it allows us to know which localities are the most visited for wild collection, especially of seeds, and so determine whether this is legal and sustainable or not. Once the harvesting localities have been determined, action plans can be created to keep these localities under surveillance during the time of fruit production. These localities can also be used as study areas to understand the population dynamics under constant harvesting.

There already exists a growing concern for the regulation of - illegally collected plants sold on the Internet (Sajeva et al. 2013, Lavorgna 2014). At this point, eBay offers the option of reporting items on sale based on their prohibited and restricted items list, which includes plants and seeds. However, this policy is focused on limiting the spread of pests and weeds and not on wildlife protection (eBay 2015). Its international trading policy expects the seller to be aware of international trade laws before listing an item and warns items could be removed if these laws are not respected; the same is applied to its animals and wildlife product policy. In this study, we see that although the policies exist they are not reflected in practice; particularly in the case of plants there is a gap of regulation in regard of protected species trade.

In the case of major online stores like eBay, Mercado Libre and Amazon we propose they apply a policy based on filtering the publications which contain the name of CITES species; for example through a downloadable format, signed by the seller 
assuming responsibility for the legal origin of the product or/and a pop up window allowing the buyer to understand what a CITES species is and what its acquisition involves. Most times the lack of compliance with regulations for wildlife trade is more a matter of ignorance rather than disobedience (see Kepel 2004). This is especially important since often buyers assume that if a product is offered on a well-known service, then it must be legal.

In regard of the cheap online prices found for this species and considering their extremely low growth rates, late and annual reproduction events, and the rare establishment of new plants in the wild; we can argue the price for this species and probably for many other cacti and slow-growing plants is undervalued. Even in the case of abundant supply or low market demand, the valorisation of this and other species is not reflecting their particularly long life cycles and the services they bring to many pollinators. Just as diamonds take a long time to form, so do many cacti take a long time to reach the aesthetically appreciated form collectors want and it takes an equally long time for new individuals to establish in wild populations; however, they are clearly valued differently.

\section{Conclusion}

We found that most of the Strombocactus plants and seeds offered for sale on-line do not mention or follow CITES international trade regulations, therefore both the legal origin of the specimens and the assurance that it was non-detrimental for the survival of the species in the wild, can be questioned.

We emphasize that most of these stores also offer other cacti (close to 50 species) listed in CITES Appendix I. This type of trade must be acknowledged and complied with to promote species conservation. Throughout this study, and in compliance with the results of Kepel (2004), amongst breeders and artificial propagators we find general acceptance for breaking nature preservation laws. So we must ask ourselves why is this so? How can we fix it? And do current regulations make it too difficult to obtain the proper documentation for those who wish to trade honestly?

Especially in species rich countries, like Mexico, we need to open our eyes to the demand for wildlife and how it can be satisfied through fair trade schemes that benefit local landowners.

\section{Acknowledgements}

This research was completed through grants from Consejo Nacional de Ciencia y Teconología and Secretaría del Medio Ambiente y Recursos Naturales (project SEMARNAT/CONACyT 0350) and Ciencia básica del Conacyt (Conacyt 221362), and by Universidad Nacional Autónoma de Mexico (project PAPIIT IN 207411) and PASPADGAPA-UNAM for sabbatical leave to MCM. 


\section{References}

Álvarez R, Gúzman U, Dávila P (2004) Aspectos ecológicos de dos cactáceas mexicanas amenazadas: Implicaciones para su conservación. Boletín de la Sociedad Botánica de México 75: 7-16.

Bárcenas RT (2003) Parte II: Los cactos del Desierto Chihuahuense en México. Una evaluación del comercio, la administración y las prioridades de conservación. In: Robbins CS (Ed.) Comercio Espinoso: Comercio y Conservación de Cactos en el Desierto Chihuahuense. TRAFFIC Northamerica and World Wildlife Fund, DC.

Carrillo IG, Golubov J, Rojas-Aréchiga M, Mandujano MC (2005) Distribución y estatus de conservación de Ferocactus robustus (Pfeiff.) Britton et. Rose. Cactáceas y Suclentas Mexicanas 50(2): 36-55.

CEEWeb CITES WG (2007) CEETEES Trade in endangered species in Central and Eastern European countries.

Ceballos E, Kepel A (2009) Report 2009: Internet trade of CITES species of animals in Ecuador. CATCA Campaign Against the Cruelty of Animals, Canada.

CITES (2011) PC11 Doc. 21.2 Comercio de cactus mexicanos: venta de cactus en internet. Eleventh reunion of the Flora Committee Langkawi (Malaysia). [3-7 Sept. 2001]

CITES (2013) A guide to using the CITES Trade Database, Version 8. UNEP World Conservation Monitoring Centre, Cambridge. http://trade.cites.org/cites_trade_guidelines/ en-CITES_Trade_Database_Guide.pdf [March, 2015]

CITES (2014) Appendices. http://www.cites.org/eng/app/appendices.php\#flora4 [13 June 2014]

CITES (2015) CITES trade statistics derived from the CITES Trade Database, UNEP World Conservation Monitoring Centre, Cambridge. [March, 2015]

Convention on Biological Diversity (2012) Global Strategy for Plant Conservation: 20112020. Botanic Gardens Conservation International, Richmond.

D'Cruze N, Singh B, Morrison T, Schmidt-Burbach J, Macdonald DW, Mookerjee A (2015) A star attraction: The illegal trade in Indian Star Tortoises. Nature Conservation 13: 1-19. doi: $10.3897 /$ natureconservation. 13.5625

eBay (2015) Prohibited and restricted items - overview. http://pages.ebay.com/help/policies/ items-ov.html [20 November 2015]

Godínez-Álvarez H, Ortega-Baes P (2007) Mexican cactus diversity: environmental correlates and conservation priorities. Boletín de la Sociedad Botánica de México 81: 81-87.

Gómez-Hinostrosa C, Sánchez E, Guadalupe Martínez J, Bárcenas RT (2013) Strombocactus disciformis. The IUCN Red List of Threatened Species 2013: e.T152318A623148. doi: 10.2305/IUCN.UK.2013-1.RLTS.T152318A623148.en

Jímenez-Sierra C, Torres-Orozco R (2003) Estado actual de las poblaciones de la biznaga dulce Echinocactus platyacanthus (Cactaceae) en el SE de Puebla. Contactos 47: 28-24.

Kepel A, Grebieniow A, Kala B (2004) Species Disappearing through the net: illegal trade in animals on the Internet in Poland. Salmandra, Polish Society for Nature Protection.

Lavorgna A (2014) Wildlife trafficking in the Internet age. Crime Science 3(1): 1-12. doi: $10.1186 / \mathrm{s} 40163-014-0005-2$ 
Martínez-Peralta C, Mandujano MC (2009) Saqueo en poblaciones naturales Ariocarpus: el caso de $A$. agavoides. Cactáceas y Suculentas Mexicanas 54(2): 60-62.

Novoa A, Le Roux JJ, Robertson MP, Wilson JRU, Richardson DM (2014) Introduced and invasive cactus species: a global review. AoB PLANTS 7: 1-14. plu078. doi: 10.1093/ aobpla/plu078

Ortega-Baes P, Godínez-Álvarez H (2006) Global diversity and conservation priorities in the Cactaceae. Biodiversity Conservation 15: 817-827. doi: 10.1007/s10531-004-1461-x

Ortega-Baes P, Sühring S, Sajama J, Sotola E, Alonso-Pedano M, Bravo S, Godínez-Álvarez H (2010) Chapter 8: Diversity and Conservation in the Cactus Family. In: Ramawat KG (Ed.) Desert Plants, 157. Springer-Verlag, Berlin, Heidelberg, 157-173. doi: 10.1007/9783-642-02550-1_8

Pistoni J, Toledo LF (2010) Amphibian illegal trade in Brazil: What do we know? South American Journal of Herpetology 5(1): 51-56. doi: 10.2994/057.005.0106

Rojas-Aréchiga M, Mandujano MC, Golubov J (2013) Seed size and photoblastism in species belonging to tribe Cacteae (Cactaceae). The Botanical Society of Japan and Springer Japan 2012 . Journal of Plant Research 126: 373-386. doi: 10.1007/s10265-012-0526-2

SEMARNAT (2010) Secretaria de medio ambiente y recursos naturales. Jueves 30 de Diciembre de 2010. Diario oficial de la federación. http://www.profepa.gob.mx/innovaportal/ file/3552/1/nom-059-semarnat-2010_30-dic-2010.pdf

U.S. Fish \& Wildlife Service (2010) September. Permits FAQ. http://www.fws.gov/permits/ faqs/faqc.html [June 13, 2014] 